\title{
Pengembangan lembar kerja siswa (LKS) berbasis model discovery learning dipadu think pair share dan pengaruhnya terhadap kemampuan berpikir kritis serta hasil belajar kognitif siswa
}

\author{
Sovi Makhmudah, Mimien Henie Irawati*, Sueb \\ Universitas Negeri Malang, Jl. Semarang No. 5 Malang, Jawa Timur, Indonesia \\ *Penulis korespondensi, Surel: mimien.henie.fmipa@um.ac.id \\ Paper received: 02-01-2021; revised: 15-01-2021; accepted: 30-01-2021
}

\begin{abstract}
This research was a research of development of student worksheet using ADDIE model. This study aimed to produce the product of student worksheet based on Discovery Learning model combined with Think Pair Share with validity test. The development model was the ADDIE model consisting of five steps: analyzing, designing, developing, implementing and evaluating. Subjects in this study were students of class X of science class 7 and X of science class 5 consisting of 38 students each class. The instrument was an expert validation sheet. The test results of validity and student worksheet by the three validators obtained average score 3.67 with percentage 91.67 and valid description. Suggestions from the results of this research are disseminating products developed through the results seminar with Biology Subject Teachers (MGMP) team, writing journal articles and developing DVD form products. Based on the research results obtained syntax model of Discovery Learning and Think Pair Share there are 6 stages: stimulation activities, problem identification and thinking, collecting data and pairing, processing data and sharing, proving data and conclusions.
\end{abstract}

Keywords: student worksheet; Discovery Learning combined Think Pair Share; critical thinking ability; cognitive learning outcomes

\begin{abstract}
Abstrak
Penelitian ini merupakan penelitian pengembangan Lembar Kerja Siswa (LKS) menggunakan model ADDIE. Penelitian ini bertujuan untuk menghasilkan produk LKS berbasis model Discovery Learning dipadu Think Pair Share yang valid dengan pengujian validitas. Model pengembangan yang digunakan yaitu model ADDIE yang terdiri dari lima langkah yaitu menganalisis (analyze), merancang (design), mengembangkan (develop), menerapkan (implement) dan mengevaluasi (evaluate). Subjek dalam penelitian ini yaitu siswa kelas X MIA-7 dan X MIA-5 yang terdiri dari 38 siswa setiap kelasnya. Instrumen yang digunakan yaitu lembar validasi ahli. Hasil uji kevalidan LKS oleh ketiga validator diperoleh rerata skor 3,67 dengan persentase 91,67 dan keterangan valid. Saran hasil penelitian ini yaitu mensosialisasikan produk yang dikembangkan melalui seminar hasil bersama tim Musyawarah Guru Mata Pelajaran (MGMP) biologi, penulisan artikel jurnal dan mengembangkan produk bentuk DVD. Berdasarkan hasil penelitian diperoleh sintaks perpaduan model Discovery Learning dan Think Pair Share ada 6 tahapan yaitu kegiatan stimulasi, identifikasi masalah dan berpikir, mengumpulkan data dan berpasangan, mengolah data dan berbagi, membuktikan data dan simpulan.
\end{abstract}

Kata kunci: LKS; kemampuan berpikir kritis; hasil belajar kognitif

\section{Pendahuluan}

Pembelajaran abad 21 dicirikan dengan pertautan berbagai disiplin ilmu secara komprehensif dan pengintegrasian teknologi dalam pendidikan. Menurut Avenue (2016) keterampilan yang harus dimiliki siswa pada abad 21 yaitu keterampilan hidup dan berkarir (life and career skills), keterampilan belajar dan berinovasi (learning and innovation skills) serta keterampilan teknologi dan media informasi (information, media, and technology skills). 
Indikator keterampilan belajar dan berinovasi meliputi: (1) berpikir kritis dan mengatasi masalah; (2) komunikasi dan kolaborasi; dan (3) kreativitas dan inovasi. Salah satu indikator keterampilan belajar dan berinovasi yaitu berpikir kritis. Menurut Ennis (2001) berpikir kritis adalah cara berpikir reflektif yang masuk akal atau berdasarkan nalar yang difokuskan untuk menemukan apa yang harus diyakini dan dilakukan. Kemampuan berpikir kritis juga dapat memengaruhi hasil belajar siswa. Semakin tinggi kemampuan berpikir kritis maka maka hasil belajar kognitif juga akan meningkat. Salah satu model pembelajaran yang sesuai dengan Kurikulum 2013 dan melatih berpikir kritis serta diharapkan dapat meningkatkan hasil belajar siswa ialah model Discovery Learning. Sani (2014: 23) menyatakan bahwa model pembelajaran discovery adalah menemukan konsep melalui serangkaian data atau informasi yang diperoleh melalui pengamatan atau percobaan. Model Discovery Learning adalah salah satu model pembelajaran dengan menemukan konsep melalui kegiatan eksperimen, namun belum memberdayakan kolaborasi yang efektif dalam prosesnya sehingga diperlukan model kooperatif yang sesuai agar pembelajaran berlangsung efektif. Hasil penelitian Astra $d k k$. (2015), Uside $d k k$. (2013), Wardhani (2014) dan Mahmoud (2014) menunjukkan pengembangan Lembar Kerja Siswa (LKS) menggunakan pendekatan Discovery Learning dapat meningkatkan motivasi, partisipasi dan hasil belajar siswa dalam proses pembelajaran menggunakan LKS. Serupa dengan hasil penelitian Setiadewi $d k k$. (2014), Duron $d k k$. (2006) menunjukkan bahwa LKS berorientasi model pembelajaran Discovery Learning dapat mengembangkan kemampuan berpikir dan hasil belajar siswa. Sementara itu, Reid $d k k$. (2003) menyimpulkan bahwa hasil keseluruhan penelitian mendukung pentingnya pembelajaran yang bermakna dan penalaran dari proses discovery serta penerapannya dalam pembelajaran.

Salah satu model pembelajaran yang efektif yaitu Think Pair Share (TPS), model ini memberikan kesempatan kepada siswa untuk bekerja sama dengan siswa lainnya dalam mengerjakan tugas. Menurut Huda (2010: 32) pembelajaran kooperatif bergantung pada keefektifan kelompok siswa tersebut. Menurut Huda (2010: 136) model pembelajaran TPS memungkinkan siswa untuk bekerja sendiri dan bekerja sama dengan orang lain, mengoptimalkan partisipasi siswa dan dapat diterapkan di semua mata pelajaran. Hasil penelitian Titsankaew (2015), Sumarsih \& Sanjaya (2013) menunjukkan bahwa model TPS dapat meningkatkan prestasi belajar siswa. Sementara itu, hasil penelitian Boleng (2014) menunjukkan bahwa model pembelajaran TPS berpengaruh sangat signifikan terhadap keterampilan berpikir kritis, sikap sosial dan hasil belajar kognitif.

Perpaduan sintaks model Discovery Learning dan TPS memungkinkan pembelajaran berlangsung efektif karena model Discovery Learning memudahkan siswa untuk menemukan konsep berdasarkan langkah pembelajaran yang sesuai pendekatan saintifik sedangkan model TPS sebagai model kooperatif yang membantu siswa bekerja sama secara berpasangan sehingga tujuan pembelajaran tercapai. Selain penerapan model pembelajaran yang sesuai juga diperlukan bahan ajar yang mendukung tercapainya kemampuan berpikir kritis, komunikasi dan berkolaborasi. Bahan ajar yang sesuai dengan kebutuhan siswa akan memudahkan siswa dalam memahami materi yang dipelajari. Prastowo (2012: 24) menyatakan bahwa LKS merupakan suatu bahan ajar cetak berupa lembaran kertas yang berisi ringkasan materi, latihan soal dan petunjuk pelaksanaan tugas pembelajaran yang mengacu pada kompetensi dasar yang harus dikerjakan siswa. 
Hasil wawancara dengan salah satu guru biologi SMA Negeri 1 Talun-Blitar pada tanggal 24 Oktober dan 23 November 2016, menunjukkan bahwa LKS yang digunakan oleh siswa belum memberdayakan siswa untuk berpikir kritis dan berkolaborasi dengan teman sejawat. Kekurangan LKS yaitu sistematika dalam LKS belum sesuai dengan pendekatan saintifik, kurang melatih kemampuan berpikir kritis pada siswa karena jawabannya menyalin pada ringkasan materi dan kurang melatih kolaborasi antar siswa sehingga kurang memberi tantangan pada siswa untuk berinovasi. Hasil angket kebutuhan siswa menunjukkan bahwa siswa masih merasa kesulitan dalam mengaitkan materi yang dipelajari di sekolah dengan fenomena yang terjadi dalam kehidupan nyata khususnya pada materi dunia tumbuhan.

Hal ini didukung dari data nilai siswa kelas X tahun lalu (2015) yang menunjukkan bahwa materi dunia tumbuhan belum mencapai kompetensi secara maksimum. Sebesar $60 \%$ nilai siswa masih di bawah KKM yaitu 80 dan pengembangan LKS yang memberdayakan potensi siswa masih belum dilakukan, oleh karena itu peneliti melakukan penelitian yang berjudul "Pengembangan Lembar Kerja Siswa (LKS) berbasis model Discovery Learning dipadu Think Pair Share dan pengaruhnya terhadap kemampuan berpikir kritis serta hasil belajar kognitif siswa". Tujuan penelitian ini yaitu menghasilkan produk LKS berbasis model Discovery Learning dipadu Think Pair Share yang valid dengan pengujian validitas. Manfaat penelitian yaitu diharapkan berpengaruh terhadap hasil belajar kognitif siswa, dapat dijadikan rujukan bagi peneliti lain dan menambah referensi guru dalam melakukan inovasi pembelajaran di dalam kelas.

\section{Metode}

LKS yang dikembangkan menggunakan model pengembangan ADDIE (Analyze, Design, Develop, Implement and Evaluate) (Branch, 2009). Tahap analisis (analyze) meliputi memvalidasi kesenjangan antara kondisi nyata dengan kondisi ideal, menentukan tujuan pengembangan, melakukan konfirmasi target, mengidentifikasi sumber daya yang diperlukan dalam pengembangan, menentukan sistem pengantar dan menyusun rencana pelaksanaan pengembangan. Tahap merancang produk (design) meliputi merancang keseluruhan komponen dalam produk, menyusun tujuan pengembangan, merancang instrumen validasi dan uji coba produk. Tahap mengembangkan produk (develop) dilakukan dengan untuk memvalidasi sumber belajar yang dipilih, kemudian akan didapatkan produk yang dibutuhkan untuk tahap implement. Tahap mengembangkan produk meliputi membuat produk sesuai rancangan, memilih atau mengembangkan media pendukung, melakukan revisi formatif dan melakukan uji coba pendahuluan.

Tahap menerapkan produk (implement) meliputi persiapan guru dan persiapan siswa. Cara pengujian pengembangan pembelajaran dilakukan dengan menggunakan quasi experiment dengan rancangan nonequivalent pretest-postest control group design. Eksperimen semu dilakukan untuk mengetahui keefektifan LKS yakni pengaruh LKS berbasis model Discovery Learning dipadu TPS terhadap kemampuan berpikir kritis dan hasil belajar kognitif siswa. Data yang diperoleh pada tahap ini berupa hasil pretest dan postest dari kemampuan berpikir kritis dan hasil belajar kognitif. Tahap akhir pada model ini yaitu evaluasi produk (evaluate). Tahap evaluasi yang dimaksud ialah proses pengumpulan data, menganalisis data yang telah diperoleh dan membuat data menjadi sesuatu yang bermakna yang digunakan untuk keputusan tentang proses dan produk yang dihasilkan. 
Data penelitian dan pengembangan untuk menguji validitas LKS dianalisis menggunakan statistik deskriptif yang kemudian dicocokkan dengan kriteria evaluasi. Rumus yang digunakan sebagai berikut.

$$
\mathrm{P}=\frac{\Sigma x}{\Sigma x i} \times 100
$$

Keterangan:

$\mathrm{P}=$ Persentase

$\Sigma \mathrm{x}=$ Jumlah jawaban responden dalam satu item

$\Sigma \mathrm{xi}=$ jumlah keseluruhan nilai ideal dalam satu item

Kriteria validitas analisis persentase disajikan dalam Tabel 1.

Tabel 1. Kriteria Validitas Analisis Persentase

\begin{tabular}{lll}
\hline Persentase (\%) & Kriteria Kevalidan & Keterangan \\
\hline 100 & Sangat valid & Tidak revisi \\
\hline $75 \leq x \leq 100$ & Valid & Sedikit revisi \\
\hline $50 \leq x \leq 75$ & Cukup Valid & Sedikit revisi \\
\hline $25 \leq x \leq 50$ & Kurang Valid & Banyak revisi \\
\hline $0 \leq x \leq 25$ & Tidak Valid & Revisi total \\
\hline & (Arikunto, 2013: 67$)$ &
\end{tabular}

\section{Hasil dan Pembahasan}

\subsection{Hasil Tahap Menganalisis (Analyze)}

Tahap menganalisis terdiri dari 6 langkah yaitu memverifikasi permasalahan, menentukan tujuan pengembangan, melakukan konfirmasi target, mengidentifikasi sumber daya yang diperlukan dalam pengembangan, menentukan sistem pengantar dan menyusun rencana pelaksanaan pengembangan. Pada tahap memverifikasi permasalahan menunjukkan LKS tersebut masih sederhana dan kurang menuntut siswa untuk berpikir kritis dalam memecahkan suatu masalah yang diberikan guru. Tahap menentukan tujuan pengembangan dilakukan dengan cara menghasilkan bahan ajar yang mengaitkan materi dengan kehidupan nyata siswa sehingga siswa lebih mudah memahami materi/konsep yang dipelajari. Tahap melakukan konfirmasi target atau sasaran pengembangan menunjukkan sebanyak $100 \%$ siswa menggunakan LKS dalam belajar biologi, LKS yang digunakan berasal dari penerbit dan bentuk LKS yang digunakan berupa menjawab pertanyaan.

Tahap mengidentifikasi sumber daya yang digunakan dalam penelitian ini yaitu sumber materi, fasilitas pembelajaran, sumber daya teknologi dan sumber daya manusia. Tahap menentukan sistem pengantar dilakukan pemilihan produk pengembangan berupa LKS berbasis Discovery Learning dipadu TPS. Tahap keenam yaitu menyusun rencana pelaksanaan dilaksanakan pada bulan Januari sampai dengan bulan Maret 2017.

\subsection{Hasil Tahap Merancang Produk (Design)}

Tahap merancang produk meliputi 3 langkah yaitu merancang keseluruhan komponen dalam produk, menyusun tujuan pengembangan, merancang instrumen validasi dan uji coba produk. Tahap merancang keseluruhan komponen dalam produk dilakukan dengan cara 
mengidentifikasi keseluruhan komponen penting yang dibutuhkan untuk mencapai tujuan pengembangan produk yaitu bagian awal, inti dan penutup. Tahap menyusun tujuan pengembangan dilakukan penyusunan bahan ajar LKS sebagai sumber belajar meliputi aspek pengetahuan/kognitif dan kemampuan berpikir kritis. Tahap merancang instrumen validasi dan uji coba produk dilakukan penyusunan instrumen validasi produk, termasuk kelayakan, kepraktisan, dan keefektifan LKS, selain itu juga disusun instrumen untuk mengetahui hasil tes pengetahuan dan kemampuan berpikir kritis.

\subsection{Tahap Mengembangkan Produk (Develop)}

Tahap mengembangkan produk dilakukan untuk menghasilkan produk selanjutnya memvalidasi produk agar dapat dilanjutnya ke tahap penerapan. Tahap membuat produk sesuai rancangan dilakukan dengan cara mengembangkan produk dengan komponen yaitu halaman/cover, kata pengantar, daftar isi, petunjuk penggunaan LKS, KD dan indikator, kegiatan belajar, ringkasan materi, soal evaluasi serta daftar rujukan. Tahap memilih/mengembangkan media dilakukan dengan cara pembuatan hal yang mendukung materi produk yang dikembangkan. Tahap ketiga yaitu revisi formatif dilakukan validasi oleh ketiga ahli yaitu ahli media, ahli materi dan ahli praktisi pendidikan. Hasil validasi ketiga pakar ditunjukkan pada tahap evaluasi. Tahap keempat yaitu melakukan uji coba pendahuluan tahap ini dilakukan uji coba pendahuluan di lapangan dalam skala kecil, yang bertujuan untuk memperoleh masukan dalam rangka mengembangkan produk akhir dari LKS. Data dikumpulkan melalui pengisian angket keterbacaan LKS oleh siswa dengan jumlah sampel sebanyak 15 orang. Hasil kepraktisan produk diperoleh skor sebesar 2414 dari total skor maksimal yaitu 2736 termasuk dalam kategori B (baik).

\subsection{Tahap Menerapkan Produk (Implement)}

Tahap ini dilakukan melalui dua langkah yaitu persiapan guru dan persiapan siswa. Pada tahap persiapan guru dilakukan dengan cara menyusun Silabus dan RPP untuk memudahkan guru dalam melaksanakan pembelajaran dan mencapai tujuan pembelajaran selama 8 pertemuan pada materi Kingdom Plantae. Pada tahap persiapan siswa dilakukan untuk mengetahui keefektifan produk melalui quasi experiment dengan rancangan nonequivalent pretest-postest control group design. Eksperimen semu dilakukan untuk mengetahui keefektifan LKS yakni pengaruh LKS berbasis model Discovery Learning dipadu TPS terhadap kemampuan berpikir kritis dan hasil belajar kognitif siswa. Hasil yang diperoleh dari tahap persiapan siswa berupa nilai pretest dan postest dari kedua variabel terikat (kemampuan berpikir kritis dan hasil belajar kognitif).

\subsection{Tahap Mengevaluasi (Evaluate)}

Tahap ini merupakan tahap yang dilakukan proses pengumpulan data dan menganalisis data yang telah diperoleh. Tujuan tahapan ini untuk mengetahui kualitas produk yang dihasilkan dan proses sebelum dan sesudah dilaksanakannya penerapan produk. Produk yang dikembangkan dalam penelitian ini berupa Lembar Kerja Siswa (LKS). Menurut Prastowo (2014), LKS merupakan suatu bahan ajar cetak berupa lembaran kertas yang berisi materi, ringkasan dan petunjuk pelaksanaan tugas pembelajaran yang harus dikerjakan siswa mengacu pada kompetensi dasar yang harus dicapai siswa. Produk LKS yang dikembangkan memudahkan siswa dalam memahami konsep dan meningkatkan 
kemampuan siswa untuk belajar siswa secara aktif. LKS yang dikembangkan menggunakan perpaduan model Discovery Learning dan TPS.

Salah satu model pembelajaran yang sesuai dengan Kurikulum 2013 dan melatih berpikir kritis serta diharapkan dapat meningkatkan hasil belajar siswa ialah model Discovery Learning. Siswa juga memerlukan keterampilan berkomunikasi dan berkolaborasi dalam memecahkan permasalahan dan dapat dicapai melalui model pembelajaran kooperatif. Salah satu model pembelajaran kooperatif yaitu TPS yang memungkinkan siswa untuk bekerja sendiri dan bekerja sama dengan orang lain. Struktur LKS yang dikembangkan meliputi cover, kata pengantar, daftar isi, petunjuk penggunaan LKS, KD dan indikator, kegiatan belajar dengan tahap Discovery Learning dipadu TPS. Produk LKS yang sudah divalidasi ahli materi, ahli media dan praktisi pendidikan yang sudah valid dan dapat digunakan setelah direvisi pada beberapa aspek yang belum layak. Revisi produk yang dikembangkan disajikan dalam Tabel 2.

Tabel 2. Revisi Lembar Kerja Siswa

\begin{tabular}{|c|c|c|c|}
\hline Bagian LKS & Validator & Sebelum Revisi & Sesudah Revisi \\
\hline Cover & Ahli materi & $\begin{array}{l}\text { Tampilan warna } \\
\text { kurang menarik }\end{array}$ & Warna dibuat lebih menarik \\
\hline $\begin{array}{l}\text { Petunjuk } \\
\text { penggunaan } \\
\text { LKS }\end{array}$ & Ahli materi & $\begin{array}{l}\text { Langkah pembelajaran } \\
\text { kurang jelas }\end{array}$ & $\begin{array}{l}\text { Langkah pembelajaran } \\
\text { disesuaikan dengan model } \\
\text { Discovery Learning dipadu TPS }\end{array}$ \\
\hline Peta konsep & Ahli materi & $\begin{array}{l}\text { Ada di tampilan awal } \\
\text { sebelum masuk } \\
\text { kegiatan pembelajaran }\end{array}$ & $\begin{array}{l}\text { Tidak perlu dicantumkan karena } \\
\text { menyesuaikan dengan model } \\
\text { discovery learning }\end{array}$ \\
\hline $\begin{array}{l}\text { KD dan } \\
\text { indikator }\end{array}$ & Ahli materi & $\begin{array}{l}\text { Penjabaran KD masih } \\
\text { perlu ditambahkan }\end{array}$ & $\begin{array}{l}\text { KD lebih dijabarkan dan } \\
\text { indikator ditambah }\end{array}$ \\
\hline Dasar teori & Ahli media & $\begin{array}{l}\text { Ditampilkan di akhir } \\
\text { kegiatan pembelajaran }\end{array}$ & $\begin{array}{l}\text { Ditampilkan di awal sebelum } \\
\text { kegiatan pembelajaran }\end{array}$ \\
\hline \multirow[t]{5}{*}{$\begin{array}{l}\text { Kegiatan } \\
\text { Pembelajaran }\end{array}$} & Ahli media & $\begin{array}{l}\text { Permasalahan dan } \\
\text { tugas belum jelas }\end{array}$ & $\begin{array}{l}\text { Permasalahan dan tugas diganti } \\
\text { dengan bahasa yang mudah } \\
\text { dimengerti siswa }\end{array}$ \\
\hline & $\begin{array}{l}\text { Praktisi } \\
\text { pendidikan }\end{array}$ & $\begin{array}{l}\text { Permasalahan lebih } \\
\text { diperjelas }\end{array}$ & $\begin{array}{l}\text { Permasalahan diganti dengan } \\
\text { fenomena yang lebih mudah } \\
\text { dipahami siswa }\end{array}$ \\
\hline & & $\begin{array}{l}\text { Gambar diperbesar } \\
\text { dan diperjelas }\end{array}$ & $\begin{array}{l}\text { Gambar dibesarkan dan gambar } \\
\text { yang kurang jelas diganti dengan } \\
\text { yang lebih jelas }\end{array}$ \\
\hline & & $\begin{array}{l}\text { Bahan amatan } \\
\text { diupayakan bahan } \\
\text { yang mudah dicari } \\
\text { siswa }\end{array}$ & $\begin{array}{l}\text { Bahan amatan diganti dengan } \\
\text { bahan amatan yang ada disekitar } \\
\text { siswa }\end{array}$ \\
\hline & Ahli materi & $\begin{array}{l}\text { Belum ada penamaan } \\
\text { takson seperti kode } \\
\text { Internasional }\end{array}$ & $\begin{array}{l}\text { Diberi nama author dibelakang } \\
\text { nama tumbuhan sesuai kode } \\
\text { Internasional taksonomi } \\
\text { tumbuhan }\end{array}$ \\
\hline Penilaian & Ahli media & $\begin{array}{l}\text { Belum mengacu pada } \\
\text { setiap kegiatan di LKS }\end{array}$ & $\begin{array}{l}\text { Mengacu pada setiap kegiatan } \\
\text { pembelajaran di LKS dengan } \\
\text { bobot yang berbeda sesuai } \\
\text { tingkat kesukaran tugas }\end{array}$ \\
\hline Skoring & Ahli media & $\begin{array}{l}\text { Belum ada skoring } \\
\text { pada LKS }\end{array}$ & $\begin{array}{l}\text { Dicantumkan skoring di bagian } \\
\text { paling belakang LKS }\end{array}$ \\
\hline
\end{tabular}


Berdasarkan hasil uji keefektifan dilakukan dengan quasi experiment. Perbedaan yang signifikan pada hasil belajar kognitif siswa menggunakan LKS berbasis model Discovery Learning dipadu TPS dan pembelajaran menggunakan LKS konvensional dapat diketahui dengan menggunakan uji anakova (jika data hasil pretest dan postest memenuhi syarat kurva normal dan variansnya homogen) dengan bantuan aplikasi SPSS for windows versi 16.0. Hasil analisis kovarian diperoleh nilai $\mathrm{p}$ sebesar $0,002(\mathrm{p}<0,05)$. Ini menunjukkan ada perbedaan kemampuan berpikir kritis menggunakan LKS berbasis model Discovery Learning dipadu TPS dengan pembelajaran yang menggunakan LKS Konvensional dan kovariat (pretest) kemampuan berpikir kritis berpengaruh terhadap kemampuan berpikir kritis siswa. Pada kelas eksperimen dengan LKS berbasis model Discovery Learning dipadu TPS siswa lebih banyak berpikir saat kegiatan penemuan dibandingkan kelas kontrol. Hal ini disebabkan kegiatan LKS dengan model Discovery Learning dipadu TPS membantu siswa dalam menemukan konsep dengan melakukan berbagai kegiatan sesuai metode ilmiah. Kegiatan yang dimaksud seperti menghimpun informasi, membandingkan, mengkategorikan, menganalisis, mengintegrasikan, mengorganisasi dan membuat simpulan. Dengan demikian siswa diharapkan dapat menemukan konsep secara mandiri dan menuangkannya dalam bahasa mereka sendiri.

Proses penemuan konsep akan lebih efektif dengan kerjasama. Duron $d k k$. (2006) menjelaskan bahwa pembelajaran aktif dapat menjadikan suasana menyenangkan antara guru dan siswa dan lebih pentingnya lagi dapat melatih siswa untuk berpikir kritis. Sementara itu, Wardhani (2014) mendefinisikan bahwa model pembelajaran discovery merupakan kegiatan pembelajaran yang melibatkan secara maksimal seluruh kemampuan siswa untuk mencari dan menemukan sesuatu (benda, manusia, atau peristiwa) secara sistematis, kritis, logis, analitis sehingga mereka dapat merumuskan sendiri penemuannya dengan penuh percaya diri. Penelitian Mahmoud (2014) membuktikan bahwa model Discovery Learning termasuk dalam pembelajaran aktif yaitu mengikutsertakan siswa dalam kegiatan belajar sehingga siswa mengalami langsung proses penemuan konsep dan menerapkan apa yang telah diketahuinya pada situasi baru. Penelitian Uside $d k k$. (2013) menunjukkan bahwa metode discovery merupakan pembelajaran kontruktivis, dimana siswa membangun dan menciptakan pengetahuannya sendiri. Hal ini karena dalam sintaks pembelajaran Discovery Learning mendorong siswa untuk berpikir dan melatih siswa untuk aktif mencari dan menemukan konsep melalui berbagai kegiatan secara sistematis, logis dan analitis. Sejalan dengan penelitian Setiadewi $d k k$. (2014) menunjukkan bahwa LKS berorientasi model pembelajaran Discovery Learning dapat mengembangkan kemampuan berpikir dan hasil belajar siswa. Sementara itu, Reid $d k k$. (2003) menyimpulkan bahwa hasil keseluruhan penelitian mendukung pentingnya pembelajaran yang bermakna dan penalaran dari proses discovery serta penerapannya dalam pembelajaran.

Perpaduan model Discovery Learning dipadu TPS menciptakan suatu proses belajar dengan tutorial sebaya. Cooperative learning ialah model pembelajaran yang mengedepankan kerjasama dalam kelompok dengan kemampuan heterogen sehingga tercipta proses tutorial teman sebaya. Hal ini sesuai dengan pendapat Lord (2001) bahwa siswa akan lebih mudah menemukan dan memahami konsep yang sulit apabila mereka mendiskusikannya konsep tersebut dengan temannya. Sejalan dengan hasil penelitian Setiadewi $d k k$. (2014), Duron $d k k$. (2006) menunjukkan bahwa LKS berorientasi model pembelajaran Discovery Learning dapat mengembangkan kemampuan berpikir dan hasil belajar siswa. Sementara itu, Reid $d k k$. (2003) menyimpulkan bahwa hasil keseluruhan penelitian mendukung pentingnya 
pembelajaran yang bermakna dan penalaran dari proses discovery serta penerapannya dalam pembelajaran.

Hasil analisis anakova hasil belajar kognitif diperoleh nilai p sebesar 0,007 $(\mathrm{p}<0,05)$ menggunakan LKS eksperimen (LKS berbasis model Discovery Learning dipadu TPS) sehingga $\mathrm{H}_{0}$ ditolak dan hipotesis penelitian diterima. Ini menunjukkan bahwa ada perbedaan hasil belajar kognitif siswa menggunakan LKS yang berbeda (LKS berbasis model Discovery Learning dipadu TPS dan LKS konvensional) dan kovariat (pretest) berpengaruh terhadap hasil belajar kognitif. Pada kelas eksperimen dengan menggunakan LKS berbasis model Discovery Learning dipadu TPS siswa lebih aktif saat kegiatan penemuan dibandingkan kelas kontrol. Hal ini disebabkan pembelajaran LKS berbasis model Discovery Learning dipadu TPS terdapat kegiatan siswa untuk memikirkan masalah secara individu kemudian berdiskusi secara berpasangan. Kegiatan memikirkan masalah sendiri akan melatih siswa untuk merumuskan masalah secara mandiri berdasarkan hasil pemikirannya. Kegiatan berkelompok kecil dengan berpasangan akan memberi kesempatan setiap siswa berbagi informasi dengan teman yang lain sehingga dapat meningkatkan pemahaman siswa.

Perpaduan model Discovery Learning dipadu TPS dapat meningkatkan hasil belajar siswa, hal ini karena kedua model menekankan pada pengalaman langsung siswa untuk menemukan konsep (student centered). Penelitian Mahmoud (2014) menyimpulkan discovery learning berhasil dalam mengembangkan kemampuan kognitif melalui pengetahuan yang telah dimiliki siswa. Hasil penelitian Astra $d k k$. (2015), Uside $d k k$. (2013), Wardhani (2014) menunjukkan pengembangan LKS menggunakan pendekatan Discovery Learning dapat meningkatkan motivasi, partisipasi dan hasil belajar siswa dalam proses pembelajaran. Tint dan Nyunt (2015) berpendapat bahwa model TPS melatih aktivitas kecepatan siswa dalam memikirkan isu atau masalah dan selanjutnya berbagi pikiran dengan lainnya. Hal ini didukung oleh hasil penelitian Valdez $d k k$. (2015) menunjukkan pembelajaran kooperatif menunjukkan peluang untuk kerja kolaboratif, belajar cepat, lebih efisien, meningkatkan ingatan dan berpikir positif pada pengalaman yang telah dialami. Sementara itu, hasil penelitian Titsankaew (2015), Sumarsih \& Sanjaya (2013) menunjukkan bahwa model TPS dapat meningkatkan prestasi belajar siswa.

\section{Simpulan}

Berdasarkan hasil pembahasan maka kesimpulan dalam penelitian ini yaitu produk Lembar Kerja Siswa (LKS) berbasis model Discovery Learning dipadu Think Pair Share dari ketiga validator memperoleh persentase kelayakan sebesar 91,67 dengan keterangan valid. Setelah dilakukan pengembangan Lembar Kerja Siswa (LKS) berbasis model Discovery Learning dipadu Think Pair Share tersebut maka disarankan agar sebaiknya mensosialisasikan produk yang dikembangkan melalui seminar hasil bersama tim Musyawarah Guru Mata Pelajaran (MGMP) biologi, penulisan artikel jurnal selanjutnya diseminarkan secara nasional/internasional dan mengembangkan produk materi Plantae dalam bentuk DVD.

\section{Daftar Rujukan}

Andi, P. (2012). Panduan Kreatif Membuat Bahan Ajar Inovatif Cetakan ke-4. Yogyakarta.

Arikunto, S. (2013). Prosedur Penelitian Suatu Pendekatan Praktik. Jakarta: Bumi Aksara.

Astra, I. M., Nasbey, H., \& Muharramah, N. D. (2015). Development of student worksheet by using discovery learning approach for senior high school student. TARBIYA: Journal of Education in Muslim Society, 2(1), 91-96. 
Boleng, D. T. (2014). Pengaruh model pembelajaran Cooperative Script dan Think-Pair-Share terhadap keterampilan berpikir kritis, sikap sosial, dan hasil belajar kognitif Biologi siswa SMA multietnis. Jurnal Pendidikan Sains, 2(2), 76-84.

Branch, R. M. (2009). Instructional design: The ADDIE approach (Vol. 722). Springer Science \& Business Media.

Duron, R., Limbach, B., \& Waugh, W. (2006). Critical thinking framework for any discipline. International Journal of Teaching and Learning in Higher Education, 17(2), 160-166.

Ennis, R. H. (1993). Critical thinking assessment. Theory into practice, 32(3), 179-186.

Lord, T. R. (2001). 101 reasons for using cooperative learning in biology teaching. The American Biology Teacher, 63(1), 30-38.

Huda, M. (2011). Cooperative Learning (Yogyakarta: Pustaka Pelajar).

Mahmoud, A. K. A. (2014). The effect of using discovery learning strategy in teaching grammatical rules to first year general secondary student on developing their achievement and metacognitive skills. International Journal of Innovation and Scientific Research, 5(2), 146-153.

P21 Partnership for 21st Century Learning. (2016). Framework for 21st century learning.

Reid, D. J., Zhang, J., \& Chen, Q. (2003). Supporting scientific discovery learning in a simulation environment. Journal of Computer Assisted Learning, 19(1), 9-20.

Sani, R. A. (2014). Pembelajaran saintifik untuk implementasi kurikulum 2013.

Setiadewi, F. S., Suryawati, E. S., \& Mahadi, I. M. (2015). Pengembangan Lembar Kerja Siswa (LKS) Berorientasi Model Pembelajaran Discovery Learning (DI) untuk Meningkatkan Kemampuan Berfikir Kreatif Siswa pada Materi Bioteknologi Kelas XII SMA (Doctoral dissertation, Riau University).

Sanjaya, D. (2013). TPS as an effective technique to enhance the students'achievement on writing descriptive texT. English language teaching, 6(12), 106-113.

Tint, S. S., \& Nyunt, E. E. (2015). Collaborative learning with think-pair-share technique. Computer Applications: An International Journal (CAIJ), 2(1), 1-11.

Titsankaew, P. (2015). The Effects of using Cooperative Learning on Student's Achievement and Attitude toward Mathematics. Mathematics Education Program, International College.

Uside, N. U., Barchock, K. H., \& Abura, O. G. (2013). Effect of discovery method on secondary school student's achievement in physics in Kenya. Chuka University Journal.

Valdez, A. V., Lomoljo, A., Dumrang, S. P., \& Didatar, M. M. (2015). Developing critical thinking through activity-based and cooperative learning approach in teaching high school chemistry. International Journal of Social Science and Humanity, 5(1), 139.

Wardani, Q. A. K. (2014). Penerapan pembelajaran discovery untuk meningkatkan motivasi dan hasil belajar IPA siswa kelas VIII-D SMP Negeri 1 Wates Kabupaten Blitar. 